\title{
Women in Translation
}

\author{
Anne Malena \\ University of Alberta, Canada
}

A lot of research has been done on women and translation since Lori Chamberlain wrote "Gender and the Metaphorics of Translation" in 1988 and argued that writing was marked "to be original and 'masculine' and translation "to be derivative and 'feminine" (254). Women's work as translators has been revalorized, women writers are being translated, women translators appear more often in fiction and gender issues in translation have raised a lot of interest among translators and scholars. This is an ongoing process and much more needs to be done in non-western cultures and traditions to discover women translators in history, to recognize their work today and to transcend the binary separating writing and translating along gender lines. Women live, breathe, write and translate just as men do; they also shine, struggle and fail just as men do. When their work will no longer need to be considered separately from that of men they will truly have achieved equality but no end to this road of discovery is yet in sight. Conferences have been and are being organized all over the world and even in Canada, where many scholars agree (see, in particular, Bassnett, 2014) exciting feminist strategies have been used and have led to important studies in feminist translation and where Luise von Flotow has recently edited a new book of essays on Translating Women (2011). It is, therefore, with great pride that we present this new issue of TransCulturAl with a special focus on "Women in Translation", which includes a selection of revised papers presented at the $12^{\text {th }}$ St. Jerome's Day Conference that took place on September 30 ${ }^{\text {th }}$, 2014, in Edmonton, Alberta, Canada, as well as new contributions on the topic. Also, we continue to receive excellent submissions from far and wide, including translations and articles on a variety of topics dealing with translation and cultural studies, and we are very pleased to be able to publish a select few in this issue.

The thematic portion includes seven articles, the first being the revised keynote address by Valerie Henitiuk, one of the original organizers of the annual conference, who discusses translating women's silences in India and other contexts. Basing her arguments on the strategies developed by Canadian feminist writers, translators and scholars she shows how important it was for them to consider translation as a performative act and how it continues to be in her own work, such as coediting a volume of short stories by women from Orissa among other projects. Translating female voices out of the silence to which they have been confined is, of course, not without risk-of misrepresentation or appropriation to name only two-but, according to Henitiuk, those risks are worth taking since thoughtful and varied acts of translation succeed in making women's writing from around the world more readily available.

The remaining six articles in this section deal with a variety of topics related to the theme of women in translation, ranging from studies of individual female writers, translators and sexist language to more personal accounts, including an interview, of women scholars who perform writing and translation, discovering both at the same time. In their study of the $20^{\text {th }}$ century Dutch 
writer, Elisabeth de Roos, Elke Brems and Dorien De Man argue that, in spite of her activities as an essayist, critic, journalist and translator, she was greatly underestimated in the literary system. This is a fascinating and unfortunately typical case of a woman's intellectual career being effaced by her husband's public stature as a writer — as opposed to her hidden responsibility and attention to his every need in the private realm.

Next, Julie Tarif focuses on how sexist language functions between French and English, and how, even in well-intentioned politically correct language in intralingual and interlingual translation, involuntary sexism rears its ugly head. In the following two contributions the reader will discover the personal journeys of one scholar, Kathryn Hellerstein, through an interview conducted by Didem Uca, and of another, Paula Pratt, who explores how she herself came to "dance with Myriam" through the creation of a play, or a "staged metaphor," of the translation process based on the prophet Myriam from the Bible and the Qu'ran. Hellerstein discusses her own processes of translating and writing poetry as well as the relationship between the two and her coming to feminism through her discovery of Yiddish female poetry. The last two papers transport readers to former Czechoslovakia and Galicia and deal with fascinating issues of language and translation, the first by Peter Hála through a portrait of Božena Slančíková, a Slovak writer who used the pseudonym Timrava, the name of a beloved mountain spring, and the second by María Reimóndez with a survey of literary translation into Galician and related issues of postcolonialism and feminism.

The articles selected for the next section include topics of sexuality in the Philippines, the retranslation of Edgar Allan Poe into Turkish and Japanese subtitles in the 2007 film There Will Be Blood. First, Marion Sales examines how missionaries translated Filipino languages into normative grammars with a special focus on the priests' representations of native sexuality, which they considered deviant, unorthodox and abominable. Next, Esra Birkan-Baydan considers Poe's poetics within the Turkish literary system through the analysis of multiple translations of two stories. Finally, Tom Kabara conducts a thorough analysis of Japanese subtitles and argues that, contrary to the usual expectations, the translation in this particular case actually manages to promote qualitative growth.

The issue concludes with four sets of translations, one of a Persian poem by Nadia Gazhanfari, another from Polish by Wioletta Polanski, the next an excerpt from an Italian popular novel by Nataliya Sharlay and finally a few self-translations of poetry by Renée von Paschen.

Please take a look at the two calls for papers included at the end of the issue. These are for future special issues and we invite you to consider posting your contributions directly on the journal site or submitted them directly to me (amalena@,ualberta.ca). The CFPs can also be found in "announcements" on the journal site: http://ejournals.library.ualberta.ca/index.php/TC/announcement 
Before closing I must thank all contributors for ensuring the quality of this issue by responding quickly to the editorial team's queries and dealing carefully with revisions. Our team was also blessed this time around with the thoughtful and efficient help of Wioletta Polanski who even found time to contribute some translations pieces. She has informed us that she wishes to remain a part of the team and I'm very grateful for this decision since in a short time she has truly become invaluable. Happy reading!

\section{REFERENCES}

Bassnett, Susan. Translation. London and New York: Routledge, 2014.

Chamberlain, Lori. "Gender and the Metaphorics of Translation". The Translation Studies Reader. Ed. Lawrence Venuti. New York: Routledge, 2012. 254-268.

Flotow, Luise von, ed. Translating Women. Ottawa: University Press of Ottawa, 2011. 